\title{
Drying Behaviors of Mint Leaves in Vacuum Freeze Drying
}

\author{
Tuğba KOVACI ${ }^{1}$ Erkan DİKMEN $^{1}$, Arzu ŞENCAN ŞAHİN*1 $^{1}$ \\ ${ }^{3}$ Isparta Uygulamalı Bilimler Üniversitesi, Teknoloji Fakültesi, Makine Mühendisliği Bölümü, 32260, \\ Isparta/TÜRKIYE \\ arzusencan@isparta.edu.tr
}

Received/Geliş: 14.11 .2019

Accepted/Kabul: 05.02.2020

\begin{abstract}
In this study, the drying behaviour of mint, which is one of the medicinal plants in freeze-drying, was investigated. The products were dried at three different temperatures $\left(40,50,60^{\circ} \mathrm{C}\right)$ and three different pressures $(30,50,80 \mathrm{kPa})$ in a freeze-drying system designed as a prototype. Drying time is decreased with increasing cabin pressure. Optimal working conditions in the freeze-drying of mint leaves were determined as $30 \mathrm{kPa}$ chamber pressure and $50^{\circ} \mathrm{C}$ drying temperature. Four thin layer drying models, namely Newton model, Tow term exponential model, Logarithmic model, and Wang and Singh model are tested to predict the drying behaviour. The Wang and Singh model has presented the best prediction that has an $\mathrm{R}^{2}$ value of 0.99687 .
\end{abstract}

Keywords: Mint, Mathematical model, Freeze-drying, Vacuum, Drying kinetics.

\section{Vakumlu Dondurma Kurutmada Nane Yapraklarının Kuruma Davranışları}

\begin{abstract}
Öz: $\mathrm{Bu}$ çalı̧̧mada, dondurarak kurutma firınında kurutulan nanenin kuruma davranışı incelenmiştir. Ürünler prototip olarak tasarlanan bir dondurarak kurutma sisteminde üç farklı sıcaklıkta $\left(40,50,60^{\circ} \mathrm{C}\right)$ ve üç farklı basınçta $(30,50,80 \mathrm{kPa})$ kurutulmuştur. Ürünlerin kuruma süresi, firın basıncının artmasıyla azalmıştır. Nane yapraklarının dondurularak kurutulmasında optimum çalışma koşulları, $30 \mathrm{kPa}$ basınç ve $50^{\circ} \mathrm{C}$ kurutma sıcaklığı olarak belirlenmiştir. Kurutma davranışını tahmin etmek için Newton modeli, Tow term üstel modeli, Logaritmik modeli ve Wang ve Singh modeli olmak üzere dört ince tabaka kurutma modeli test edilmiştir. Wang ve Singh modeli, $0.99687^{\prime}$ lik bir $\mathrm{R}^{2}$ değeriyle en iyi tahmin modeli olmuştur.
\end{abstract}

Anahtar kelimeler: Nane; Matematiksel model; Dondurarak kurutma; Vakum; Kurutma kinetiği.

\section{Introduction}

Food processing has been a significant research subject worldwide in science and engineering [1]. The food drying usually used for preserving food safety is extended the shelf life of the food [2]. At the present time, much importance was given to the quality of foods during drying, and varied new drying methods were preferred in the technology of food drying. The purposes of food drying besides physically changes which occur during drying entirely act on the quality of the dried food. The critical factors such as drying temperature, drying time affect the physical properties of the dried materials [3].

The aromatic and medical leaves, such as mint leaves, can be used fresh or stored in a cool place for a short time. These products are perishable because of the high percentage of water [4]. Freeze 
drying is a used drying technic to obtain high quality dried products. It is commonly used in the pharmaceutical and food industries due to it allows the removal of water from the sensitive food products at low temperatures. This process reduces the rate of thermal and chemical degradation. It limits the microbiological activity keeps the original taste and aroma in dried nutrition products and provides products with excellent structural bonding properties [5-8]. Despite these advantages, because of its complexity, high capital investment and operating costs, its uses are mostly restricted to heat-sensitive materials with high value [1].

Many various studies have been conducted to determine the drying characteristics of different products. Wang et al. investigated porous and solid frozen samples to freeze-drying of coffee. The freeze-drying process could be significantly improved by the using of frozen porous material compared with the solid material. Drying with radiation and contact heating was shorten the drying time by $36.4 \%$. Also, the frozen porous material was determined to have a broader range of operating temperatures [9]. Younis et al. studied experimentally that infrared radiation (IR) drying of garlic slices at different radiation intensity and different airflow velocity. According to the study results, the Pabis and Modified Henderson model was satisfactory to predict the performance of product drying. The activation energy was increasing in the increasing of airflow velocity and the decreasing of infrared radiation intensity [2]. Dziki et al. carried out the freeze-drying process of kale at different temperatures for whole leaves and pulped leaves. The drying kinetics of both kale pulp and kale leaves were best fitted by the Page mathematical model [10]. Dikmen et al. investigated the drying characteristics of fresh parsley, sweet basil, and dill leave in freeze-drying at different temperatures. The best models were the Henderson and Pabis model for dill, the two-term model for parsley, and the logarithmic model for sweet basil [11]. Celen et al. carried out modelling of drying behaviour using microwave conveyor dryer assisted solar energy [12].

The drying characteristics of a specific product, dryer energy requirements and cost efficiency are the primary considerations while designing a dryer. In the design and process of a dryer, simulation models were needed [13]. The objectives of this study are expressed as follows:

1) to install a prototype vacuum freeze-dryer consisting of drying unit, cooling unit and automation unit.

2) to explore the drying characteristics of mint leaves at drying temperature of 40,50 and $60^{\circ} \mathrm{C}$ and at pressures of 30,50 , and $80 \mathrm{kPa}$.

3) to establish a suitable mathematical thin-layer model to predict drying behavior.

\section{Experimental Section}

\subsection{Dryer Set-up and Process}

The freeze-drying is a process in which water in the product is frozen, followed by its removal water from the product by firstly sublimation and after that by desorption. In lyophilization, the whole process is carried out at low temperature and pressure, so this method is suitable for drying heat-sensitive compounds [14]. Besides the advantages, the high operating cost of the freeze-drying is a significant disadvantage [15].

A prototype of the vacuum freeze-drying system was installed at the Department of Mechanical Engineering, Isparta University of Applied Sciences, Turkey. The basic working scheme of the vacuum freeze-drying system used in this study was given in Figure 1. The drying system consists of three main parts: drying unit, cooling unit, and automation unit. During the freezing process of the system, the drying oven works like a freezer. 


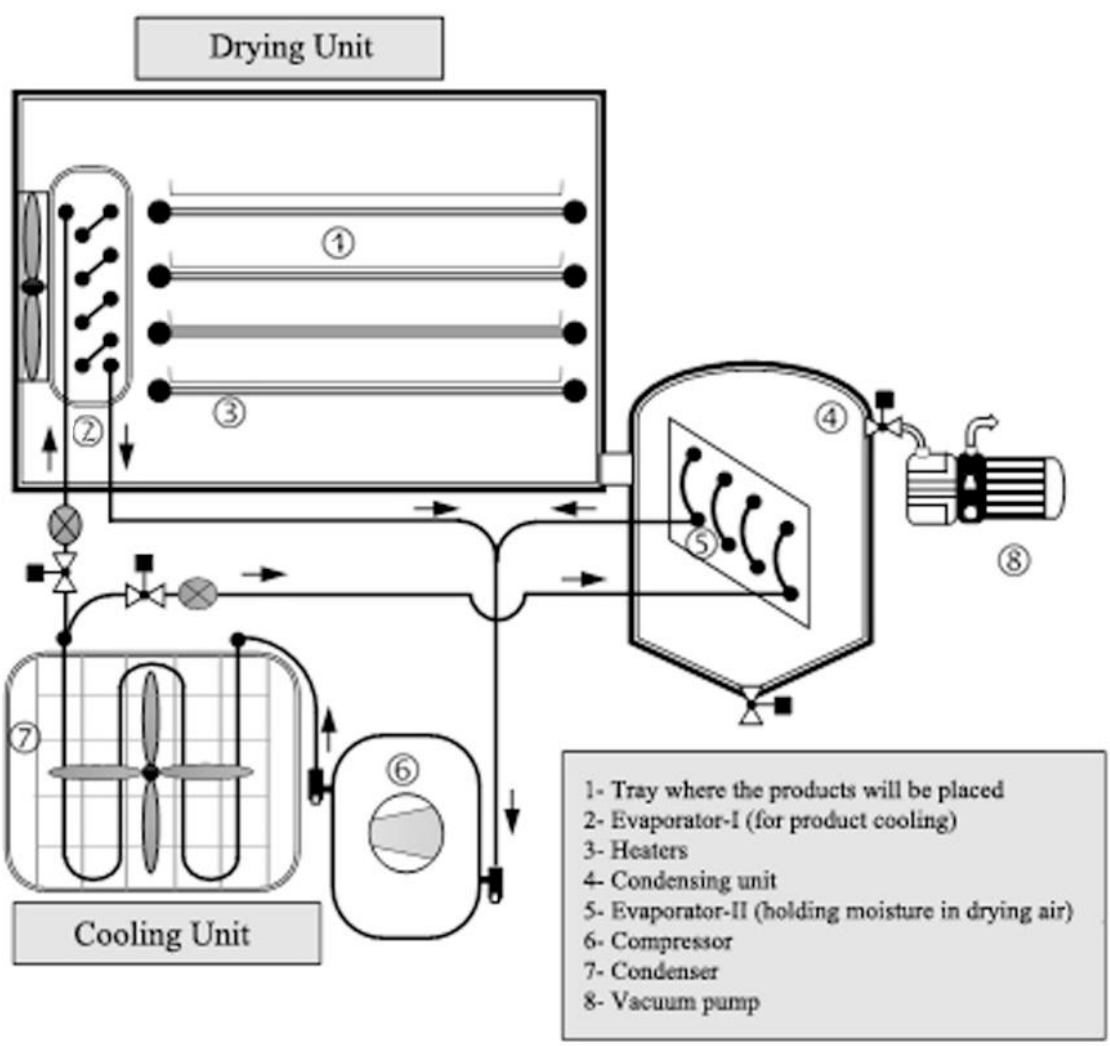

Figure 1. A schematic diagram of the freeze-drying system

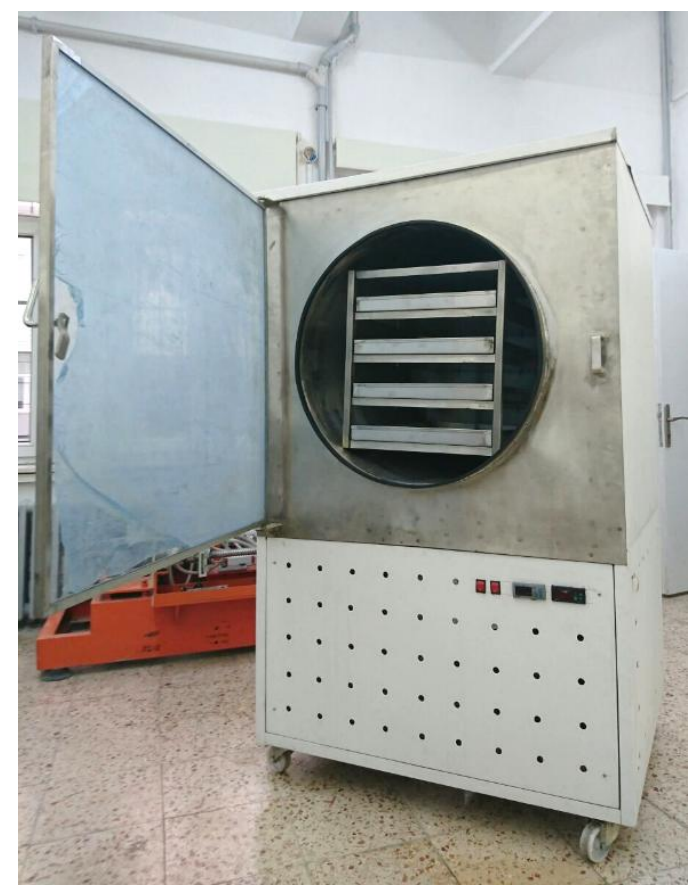

Figure 2. Freeze-drying system photograph

Cooling unit; it provides the freezing of the product, providing the vacuum pressure necessary for the frozen product to dry without thawing and freezing the water vapour generated during the drying process. Since the freezing of the product and the freezing of evaporating moisture are at different times, the cooling system was designed as a single compressor, a single condenser, and a double evaporator. One evaporator was used for freezing the product, and other evaporator used for 
freezing the water vapour separated from the product. The system was controlled by the programmable logic controller (PLC) automation system. The freeze-drying system photograph has been seen in Figure 1 and 2 [16].

The freeze-drying process is usually indicated by shelf temperature and pressure in the chamber. During the freezing process, the product was frozen at $-15^{\circ} \mathrm{C}$ freezing temperature. After the products were solidified, the drying chamber was operated at pressures of 30,50 , and $80 \mathrm{kPa}$. In order to provide sublimation energy, the products were dried at three different temperatures such as 40,50 , and $60^{\circ} \mathrm{C}$. The primary drying step in which the water was removed by sublimation of ice was completed. The experiments were performed for $100 \mathrm{gr}$ product. The measured values were recorded hourly. Technical specifications of the designed freeze-drying system were given in Table 1.

\begin{tabular}{lc} 
Table 1. Technical specifications of the freeze-drying system \\
\hline Cooling source temperature & $-30^{\circ} \mathrm{C}$ \\
Volume & $272 \mathrm{lt}$ \\
Drying tray dimensions & $40 \times 60 \mathrm{~cm}$ \\
Number of drying tray & 2 \\
Heating power of the drying system & $1500 \mathrm{~W}$ \\
Cooling capacity & $1500 \mathrm{~W}$ \\
Vacuum pump power & $745 \mathrm{~W}$ \\
Compressor power of the cooling system & $450 \mathrm{~W}$ \\
Refrigerant & $\mathrm{R} 404 \mathrm{a}$ \\
\hline
\end{tabular}

\subsection{Mathematical Modeling}

It is essential to accurately model the drying behaviour to better investigate mint drying properties [17]. In this section, the mathematical modelling has been made on the drying values obtained for $50^{\circ} \mathrm{C}$ drying temperature and $30 \mathrm{kPa}$ vacuum pressure, which is the most ideal of the nine experiments performed under different temperature and pressure conditions.

For the purpose of selecting the best-fit drying model, four thin layer mathematical models in the literature were compared with experimental data. The literature equations of the four commonly used thin-layer mathematical models were given in Table 2.

Table 2. Thin-layer drying model equations

\begin{tabular}{cllc}
\hline Model no & \multicolumn{1}{c}{ Name } & \multicolumn{1}{c}{ Equation } & Reference \\
\hline 1 & Newton & $\mathrm{MR}=\exp (-\mathrm{kt})$ & {$[18]$} \\
2 & Wang and Singh & $\mathrm{MR}=1+\mathrm{at}+\mathrm{bt}^{2}$ & {$[19]$} \\
3 & Logarithmic & $\mathrm{MR}=\mathrm{a} * \exp (-\mathrm{kt})+\mathrm{c}$ & {$[11]$} \\
4 & Two term exponential & $\mathrm{MR}=\mathrm{a} \exp (-\mathrm{kt})+(1-\mathrm{a}) \exp (-\mathrm{kat})$ & {$[20]$} \\
\hline
\end{tabular}

The established mathematical model was validated by three parameters, such as the root mean square error (RMSE), coefficient of determination $\left(\mathrm{R}^{2}\right)$, and the reduced chi-square $\left(\chi^{2}\right)$. These parameters can be calculated as follows [21,22]:

$$
R^{2}=\frac{\text { STotal }- \text { SError }}{\text { STotal }}
$$

Where; 


$$
\begin{aligned}
& \text { STotal }=\sum_{\mathrm{i}=1}^{\mathrm{n}}\left(\mathrm{MR}_{\text {exi }}-\mathrm{MR}_{\mathrm{av}}\right)^{2} \\
& \text { SError }=\sum_{\mathrm{i}=1}^{\mathrm{n}}\left(\mathrm{MR}_{\mathrm{ex} \mathrm{i}}-\mathrm{MR}_{\text {pre } \mathrm{j}}\right)^{2} \\
& \text { RMSE }=\sqrt{\frac{\sum_{i=1}^{\mathrm{m}}\left(\mathrm{MR}_{\mathrm{ex}, \mathrm{i}} \mathrm{TMR}_{\mathrm{pre}, \mathrm{i}}\right)^{2}}{N}} \\
& \chi^{2}=\frac{\sum_{\mathrm{i}=1}^{\mathrm{m}}\left(\mathrm{MR}_{\mathrm{ex}, \mathrm{i}}-\mathrm{MR}_{\mathrm{prE}, \mathrm{i}}\right)^{2}}{N-z}
\end{aligned}
$$

where $\mathrm{MR}_{\mathrm{ex}, \mathrm{i}}, \mathrm{MR}_{\mathrm{pre}, \mathrm{i}}, \mathrm{MR}_{\mathrm{av}}$ are showed the experimental moisture ratio, predicted moisture ratio and the average moisture ratio, respectively. The $\mathrm{z}$ is the number of constants in the model, and $\mathrm{N}$ is the number of observations.

\section{Results and Discussion}

\subsection{Drying Behavior}

Products were frozen at about $15{ }^{\circ} \mathrm{C}$. Frozen products were dried to the desired temperature. In the drying step, various combinations were used at a drying temperature of 40,50 , and $60{ }^{\circ} \mathrm{C}$ and a vacuum pressure of 30,50 , and $80 \mathrm{kPa}$. Drying times were longer in the primary drying period than in the secondary drying period. In general, the drying times of the products were shortened at high temperatures, but when the dry products were examined, it was determined that they physically deformed at a drying temperature of $60^{\circ} \mathrm{C}$. Therefore, in the vacuum freeze-drying of mint, the maximum critical temperature for cabin pressure of $30 \mathrm{kPa}$ was determined as $50^{\circ} \mathrm{C}$.

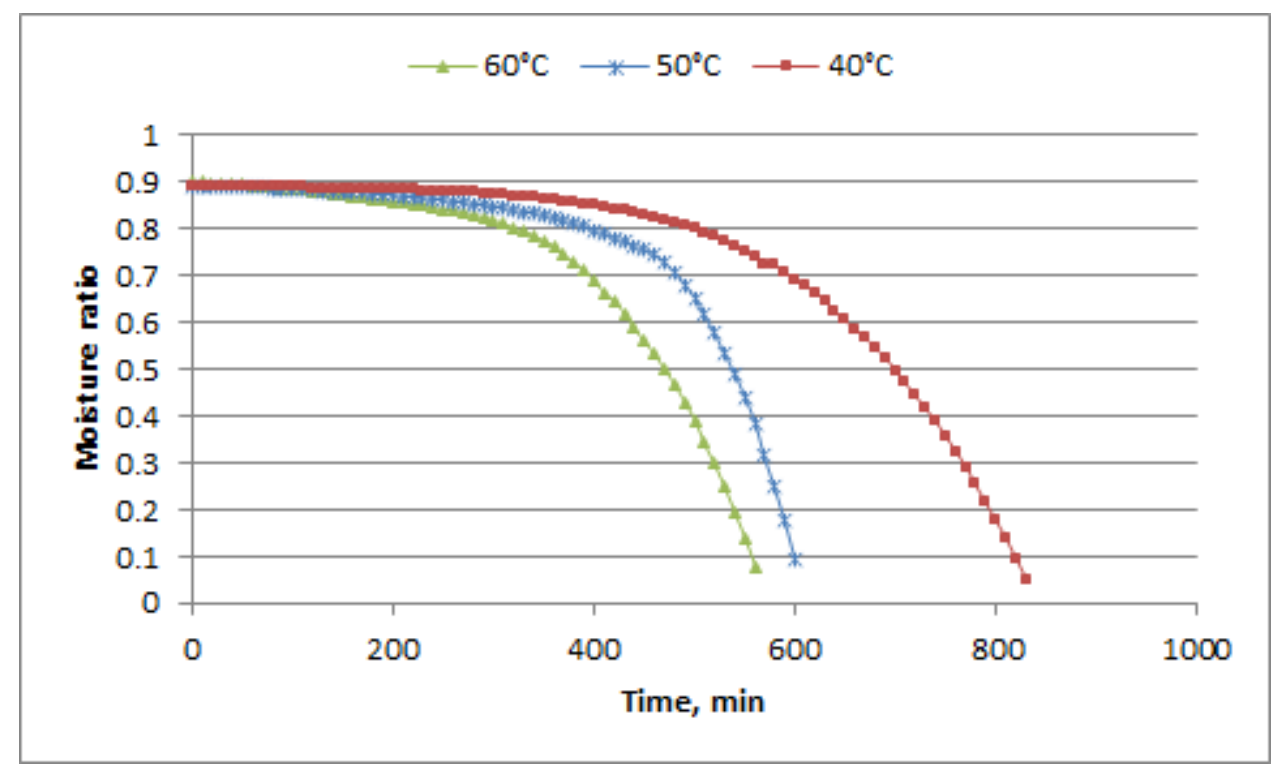

Figure 3. Moisture ratio curve as a function of time at different drying temperature $(30 \mathrm{kPa}$ pressure)

The drying kinetics of the products were shown in Figure 3 and 4. The initial moisture ratio was about 0.9 . The final moisture ratio of products was about 0.1 . Dried products at 40,50 , and $60^{\circ} \mathrm{C}$ temperatures have been reached about $0.1 \mathrm{~kg}_{\text {water }} / \mathrm{kg}_{\text {drymatter }}$ at 810,610 , and $550 \mathrm{~min}$ drying time, respectively. Dried mint leaves at 30,50 , and $80 \mathrm{kPa}$ drying pressures have been reached about 0.1 $\mathrm{kg}_{\text {water }} / \mathrm{kg}_{\text {drymatter }}$ at 580,585 , and 600 min drying time, respectively. At constant pressure, although the increase in drying temperature does not cause considerable differences at the beginning of drying, it has been a positive effect with temperature on the drying times that follow. With a temperature increase of $20^{\circ} \mathrm{C}$, the drying time of products were shortened by $32 \%$. As expected, the 
drying time was decreased with increasing pressure. With a pressure decrease of $50 \mathrm{kPa}$, the drying time of products was increased by $4 \%$.

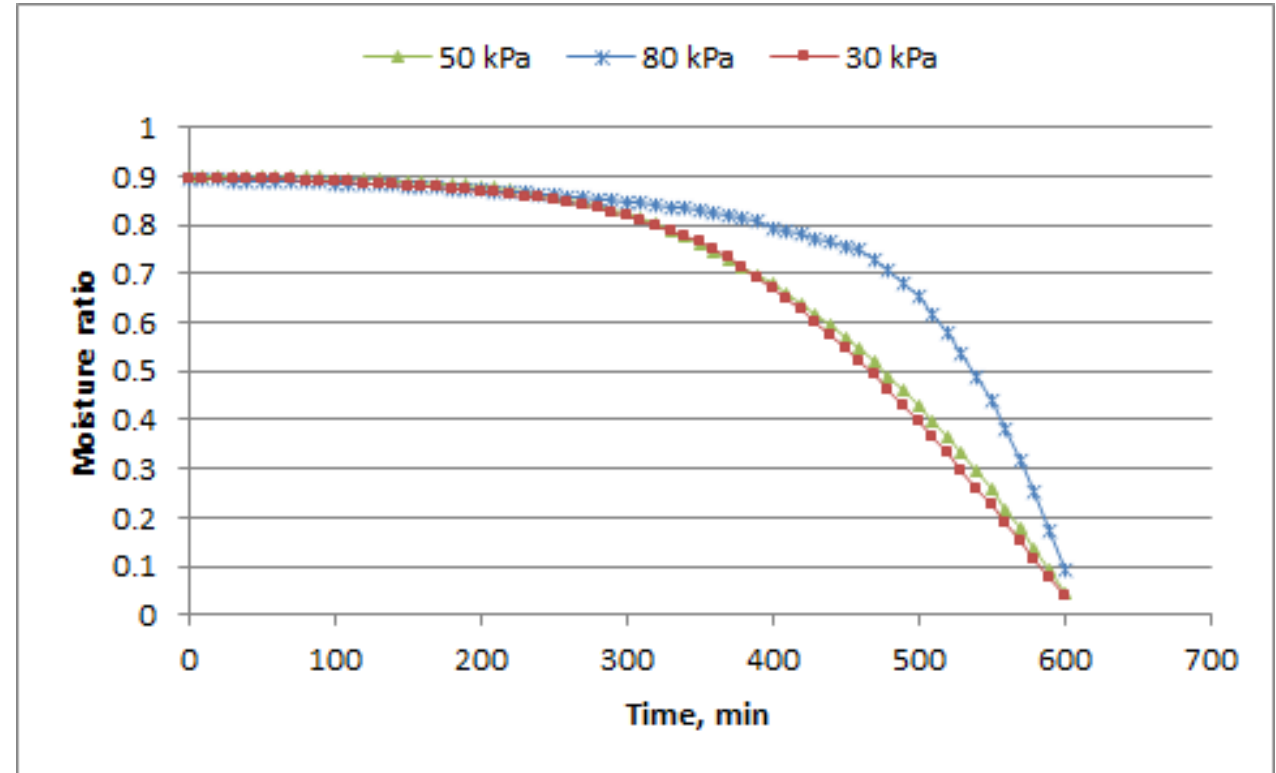

Figure 4. Moisture ratio curve as a function of time at different pressure $\left(50^{\circ} \mathrm{C}\right.$ drying temperature $)$

Figure 5 was showed the change in products and the chamber. The chamber temperature was found to be generally $1.5-4^{\circ} \mathrm{C}$ higher than the material temperature. These controllable factors are the external characteristic drying conditions of the material rather than the surrounding itself. Under the same conditions, the lower drying temperature was provided better quality products. An increase in drying temperature was affected by some chemical reactions in the products.

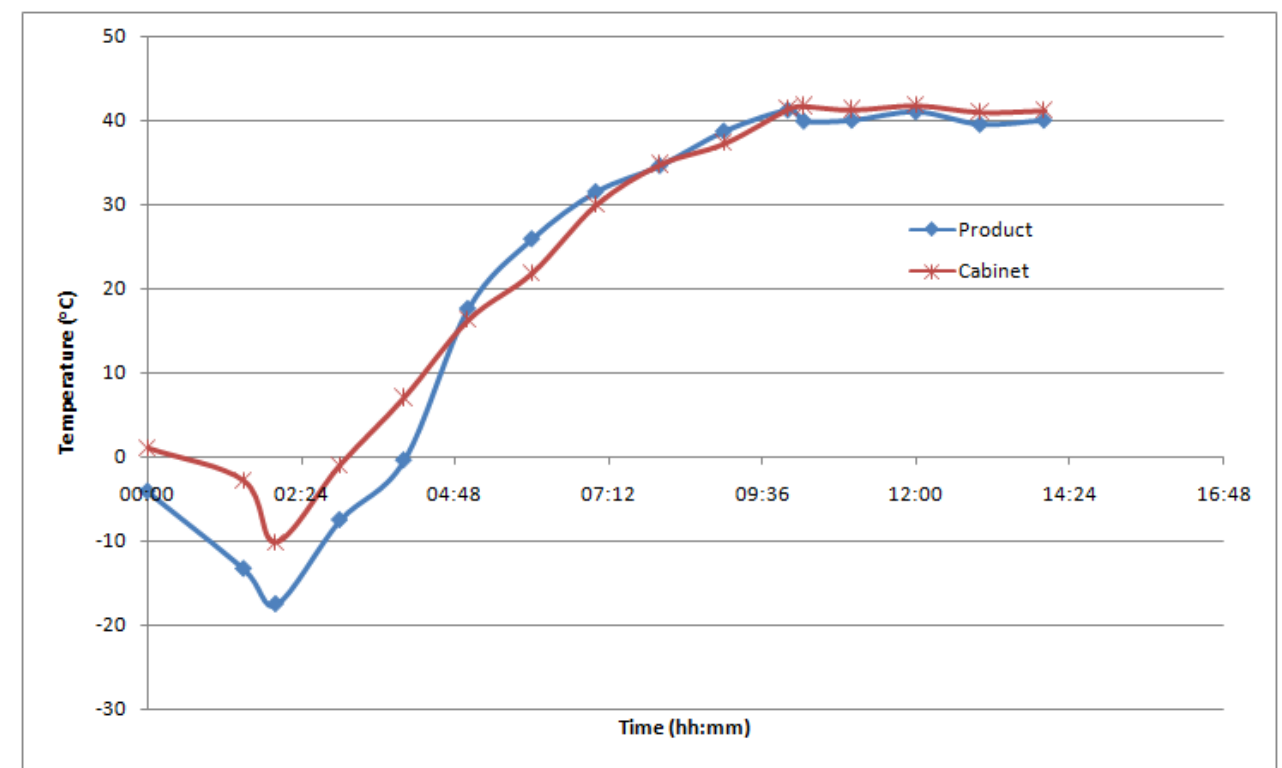

Figure 5. Product and chamber temperature curves at $30 \mathrm{kPa}$ chamber pressure and $50^{\circ} \mathrm{C}$ drying temperature

During the drying process, the change of air humidity in the drying chamber was given in Figure 6. In the first part of this plot, during the freezing phase, the chamber temperature was decreased over time; therefore, the chamber humidity was decreased, and then it was increased. At the end of approximately three hours, as the drying time was increased, the chamber humidity was continued to decrease with increasing temperature. 


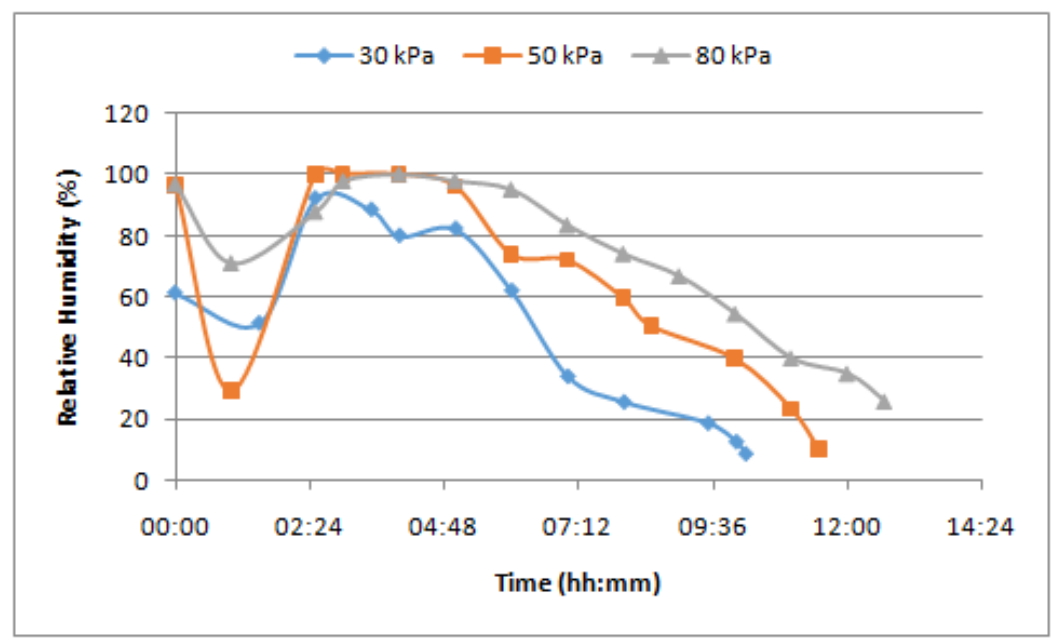

Figure 6. Change of chamber moisture at different temperatures (30 $\mathrm{kPa}$ pressure)

The moisture ratio obtained from $50^{\circ} \mathrm{C}$ drying temperatures and $50 \mathrm{kPa}$ pressure of products has been generally fit at all of four thin-layer drying models. The empirical constant and statistical values were given in Table 3.

Table 3. Statistical values and empirical constants of products

\begin{tabular}{|c|c|c|c|c|}
\hline Model & Constant & $R^{2}$ & RMSE & $\mathrm{X}^{2}$ \\
\hline Newton & $\mathrm{k}=0.00248$ & 0.86474 & 0.08572 & 0.00171 \\
\hline $\begin{array}{l}\text { Wang and } \\
\text { Singh }\end{array}$ & $\begin{array}{l}a=-0.00132 \\
b=-9.41096\end{array}$ & 0.99687 & 0.02185 & 0.00044 \\
\hline $\begin{array}{l}\text { Tow term } \\
\text { exponential }\end{array}$ & $\begin{array}{l}\mathrm{k}=1.56199 \\
\mathrm{a}=0.00158\end{array}$ & 0.86259 & 0.08596 & 0.00175 \\
\hline Logarithmic & $\begin{array}{l}\mathrm{a}=19.18078 \\
\mathrm{k}=0.00009 \\
\mathrm{c}=-18.16456\end{array}$ & 0.99523 & 0.03596 & 0.00074 \\
\hline
\end{tabular}

The values of $\mathrm{R}^{2}$ varied from 0.86474 to 0.99687 for products. The RMSE values ranged from 0.02185 to 0.08596 , whereas $\chi^{2}$ values were found to be varying from 0.00044 to 0.00175 for products. The constants and coefficients of the Wang and Singh thin-layer drying model, which has the highest $\mathrm{R}^{2}$ and lowest RMSE values was fitted better than other models $\left(\mathrm{R}^{2}=0.99687\right.$, $\left.\mathrm{RMSE}=0.02185, \chi^{2}=0.00044\right)$.

Experimental and estimated values were given in the graph in Figure 7 comparatively. It can be seen in the figure that the predicted values and the observed values with this model have a slope angle of $45^{\circ}$. 


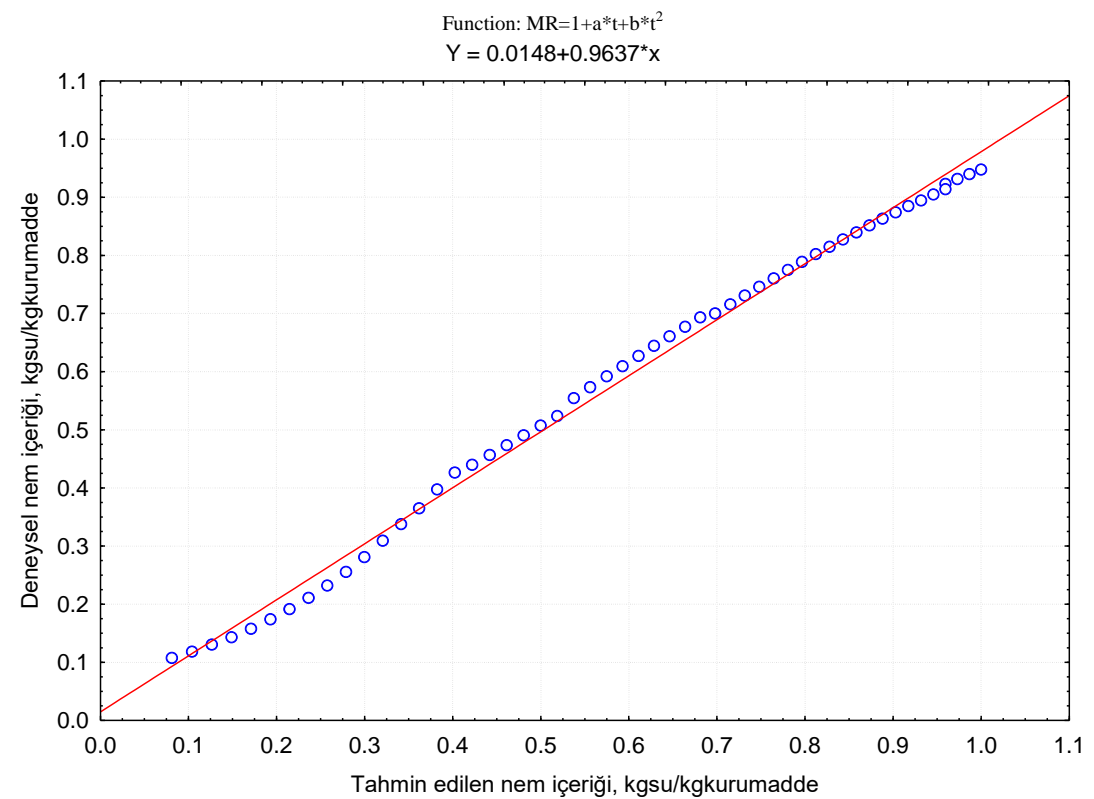

Figure 7. Comparison of experimental and predicted values for Wang and Singh model

\section{Conclusion}

In this study, the experimental freeze-drying system was installed. Mint leaves were used as a product to test the system. The mint leaves were dried at three different pressures $(30,50$, and 80 $\mathrm{kPa})$ and three different drying temperatures $\left(40,50\right.$, and $\left.60^{\circ} \mathrm{C}\right)$. The freezing temperature of the products was determined as $-15^{\circ} \mathrm{C}$. The initial moisture content of the mint was determined as 0.89 $\mathrm{kg}_{\text {water }} / \mathrm{kg}_{\text {drymatter }}$.

When the drying behaviour of the products was examined, the following results were obtained:

- Drying times were longer in the primary drying period than in the secondary drying period.

- With an increase in drying temperature, the drying time of products was reduced.

- In the freeze-drying of mint leaves at specified pressures and temperatures, the drying conditions that do not cause physical deformation and minimize energy requirements were determined as $30 \mathrm{kPa}$ chamber pressure and $50^{\circ} \mathrm{C}$ drying temperature.

- The chamber temperature was found to be generally $1.5-4^{\circ} \mathrm{C}$ higher than the temperature of the dried products. During the drying phase of the products, chamber humidity was decreased with increasing temperature.

- A mathematical model was developed with experimental results obtained in the freezedrying of mint. This model was fitted to the drying data has an $\mathrm{R}^{2}$, RMSE and $\chi^{2}$ values of $0.99687,0.0218$ and 0.00044 , respectively.

The results showed that the drying characteristics of mint leaves significantly are affected by the drying temperature and pressure. Generally, the obtained scientific findings showed that the Wang and Singh model provided a little superior simulation than the other models for determining the drying characteristics of mint leaves. This model will be useful for determining the moisture ratio values of mint leaves at appropriate accuracy.

\section{Acknowledgement}

Authors wish to thank the Süleyman Demirel University Research Foundation (SDUBAP) financial support under Project Number: 4822-D1-16. 


\section{References}

[1]. Hii, C.L., Jangam, S.V., Chiang, C.L., Mujumdar, A.S., "Processing and Drying of Foods , Vegetables and Fruits". 141, 2013.

[2]. Younis, M., Abdelkarim, D., Zein El-Abdein, A., "Kinetics and Mathematical Modeling of Infrared Thin-Layer Drying of Garlic Slices". Saudi J Biol Sci, 25(2), 332-338, 2018.

[3]. Giri, S.K., Prasad, S., "Quality Characteristics of Microwave-Vacuum Dried Button Mushrooms (Agaricus Bisporus)". Octa Journal of Biosciences, 1(1), 24-31, 2013.

[4]. Boggia, R., Zunin, P., Hysenaj, V., Bottino, A., Comite, A., "Dehydration of Basil Leaves and Impact of Processing Composition". 645-653, 2015.

[5]. Srinivasan, G., Muneeshwaran, M., Raja, B., "Numerical Investigation of Heat and Mass Transfer Behavior of Freeze Drying of Milk in Vial". Heat and Mass Transfer, 1(9), 2019.

[6]. Bourlès, E., de Lannoy, G., Scutellà, B., Fonseca, F., Trelea, I.C., Passot, S., "Scale-Up of Freeze-Drying Cycles, the Use of Process Analytical Technology (PAT), and Statistical Analysis". 215-240, 2019.

[7]. Kovacı, T., Dikmen, E., Şahin, A.Ş., "Kurutma Sistemleri, Enerji Tüketimleri ve Ürün Kalitesine Etkileri ve Örnek Sistem Tasarımı". Journal of Technical Sciences, 8(2), 25-39, 2018.

[8]. Hui, Y.H., Handbook of Fruits and Fruit Processing. Blackwell Publishing, 668, 2006.

[9]. Wang, W., Wang, S., Pan, Y., Yang, J., Zhang, S., Chen, G., "Porous Frozen Material Approach to Freeze-Drying of Instant Coffee". Drying Technology, 1-11, 2019.

[10]. Dziki, D., Polak, R., Rudy, S., Krzykowski, A., Gawlik-Dziki, U., Różyło, R., Miś, A., Combrzyński, M., "Simulation of the Process Kinetics and Analysis of Physicochemical Properties in the Freeze Drying of Kale". International Agrophysics, 32(1), 49-56, 2018.

[11]. Dikmen, E., Ayaz, M., Kovac1, T., \& Şencan Şahin, A., "Mathematical modelling of drying characteristics of medical plants in a vacuum heat pump dryer". International Journal of Ambient Energy, 40(6), 616-623, (2019).

[12]. Çelen, S., Arda, S.O., Karataşer, M.A., "Güneş Enerji Destekli Mikrodalga Konveyör Kurutucu Kullanılarak Kuruma Davranışının Modellenmesi". El-Cezeri Journal of Science and Engineering, 5(1), 267-271, 2018.

[13]. Sharma, G.P., Verma, R.C., Pathare, P., "Mathematical Modeling of Infrared Radiation Thin Layer Drying of Onion Slices". Journal of Food Engineering, 71(3), 282-286, 2005.

[14]. Nireesha, G., Divya, L., Sowmya, C., Venkateshan, N., Babu, M.N., Lavakumar, V., "Lyophilization/Freeze Drying-An Review". International Journal of Novel Trends in Pharmaceutical Sciences, 3(4), 2013.

[15]. Shofian, N.M., Hamid, A.A., Osman, A., Saari, N., Anwar, F., Dek, M.S., Hairuddin, M.R., "Effect of Freeze-Drying on the Antioxidant Compounds and Antioxidant Activity of Selected Tropical Fruits". Int J Mol Sci, 12(7), 4678-92, 2011.

[16]. Kovacı, T., Dondurarak Kurutma Sistemi Tasarımı ve Tıbbi Aromatik Ürünlerin Kurutma Parametrelerinin Araştırılması, Doktora Tezi, Isparta Uygulamalı Bilimler Üniversitesi, Isparta, Turkiye, 81, 2019.

[17]. Dhanushkodi, S., Wilson, V.H., Sudhakar, K., "Mathematical Modeling of Drying Behavior of Cashew in a Solar Biomass Hybrid Dryer". Resource-Efficient Technologies, 3(4), 359364, 2017.

[18]. Benseddik, A., Azzi, A., Zidoune, M.N., Allaf, K., "Mathematical Empirical Models of ThinLayer Airflow Drying Kinetics of Pumpkin Slice". Engineering in Agriculture, Environment and Food, 11(4), 220-231, 2018.

[19]. Argo, B.D., Sandra, S., Ubaidillah, U., "Mathematical Modeling on the Thin Layer Drying Kinetics of Cassava Chips in a Multipurpose Convective-Type Tray Dryer Heated by A Gas Burner". Journal of Mechanical Science and Technology, 32(7), 3427-3435, 2018. 
[20]. Jian, F., Jayas, D.S., "Characterization of Isotherms and Thin-Layer Drying of Red Kidney Beans, Part I, Choosing Appropriate Empirical and Semitheoretical Models". Drying Technology, 1-11, 2018.

[21]. Mitra, J., Shrivastava, S.L., Srinivasa Rao, P., "Vacuum Dehydration Kinetics of Onion Slices". Food and Bioproducts Processing, 89(1), 1-9, 2011.

[22]. Artnaseaw, A., Theerakulpisut, S., Benjapiyaporn, C., "Drying Characteristics of Shiitake Mushroom and Jinda Chili During Vacuum Heat Pump Drying". Food and Bioproducts Processing, 88(2-3), 105-114, 2010. 